\title{
Applied research on dairy cattle feeding systems in Colombian high tropics
}

\author{
Investigación aplicada en sistemas de alimentación de bovinos de \\ leche en el trópico alto colombiano
}

Javier Castillo ${ }^{\text {; }}$ Juan Benavides ${ }^{2}$; Juan Vargas ${ }^{3}$; Yesid Avellaneda ${ }^{\text {; }}$ Gustavo García ${ }^{5}$

\begin{abstract}
ARTICLE DATA
1 Researcher, Agro-ecological Engineer, Corporación Colombiana de Investigación Agropecuaria - Agrosavia, Mosquera, Colombia, jcastillos@agrosavia.co.

2 Researcher, M.Sc., Corporación Colombiana de Investigación Agropecuaria - Agrosavia, Mosquera, Colombia, jbenavidez@agrosavia.co.

3 Researcher, M.Sc. Corporación Colombiana de Investigación Agropecuaria - Agrosavia, Mosquera, Colombia, jvargasm@agrosavia.co.

4 Researcher, Ph.D., Corporación Colombiana de Investigación Agropecuaria - Agrosavia, Mosquera, Colombia, yavellaneda@agrosavia.co.

5 Researcher, Ph.D. Corporación Colombiana de Investigación Agropecuaria - Agrosavia, Mosquera, Colombia.ggarcia@agrosavia.co.
\end{abstract}

Cite: Castillo, J.; Benavides, J.; Vargas, J.; Avellaneda, Y.; García, G. (2019). Applied research on dairy cattle feeding systems in Colombian high tropics. Revista de Ciencias Agrícolas. 36(2): 108-122. doi: https://doi.org/10.22267/ rcia.193602.122

Received: October 262018.

Accepted: September 112019.

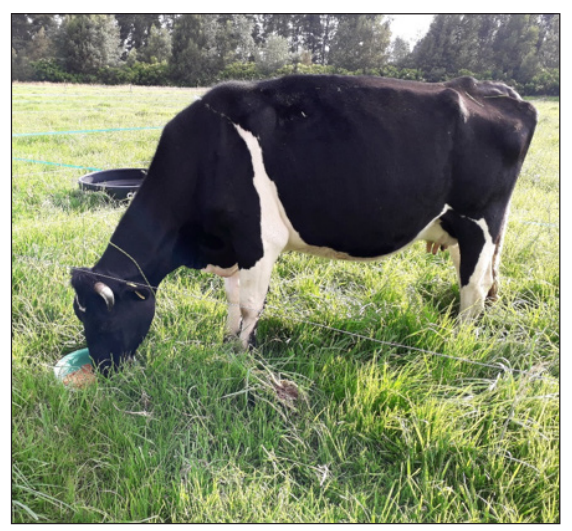

\section{ABSTRACT}

Sustainable intensification of dairy production is a strategy to consolidate a competitive sector. However, technologies adoption is limited due to the difficulty to accessing to research results. The objective of this document was to review a compilation of research works carried out mainly by the Colombian Agricultural Research Corporation (Agrosavia) in specialized dairy feeding systems of Colombian high tropics. In soils issue, research has been carried out on soil recovery and grassland renewal. Recently, the growth of grasses has been evaluated under different environmental conditions to generate efficient forage management schemes. In 2018 was registered Altoandina oat to forage use, but, in Colombian high tropic, there is a limited offer to forages due to absence of breeding program and evaluation of germplasm. Integrated management of Collaria scenica has been developed. Characterization and use of tree and shrub species have been carried out to silvopastoral systems (SSPs). In feeding systems, Agrosavia has been working on determining chemical and nutritional compositional of feed resources and design of supplementation schemes to improve animal response. Methane production increases when mature forage species are used, contrary a balanced diet or grazing in SSPs reduces methane emissions. Finally, research developments must incorporate and recognize the production costs of the system to ensure the adoption of technologies.

Key words: Production costs; dairy cattle; grazing management; forage production; silvopastoral systems.

\section{RESUMEN}

La intensificación sostenible de la producción láctea es una estrategia para consolidar un sector competitivo. Sin embargo, la adopción de tecnologías es limitada debido, entre otras cosas, a la dificultad para acceder a los resultados de investigación. El objetivo de este trabajo fue realizar una compilación de trabajos de investigación realizados principalmente por la Corporación Colombiana de Investigación Agropecuaria (Agrosavia) en sistemas de alimentación de lechería especializada del trópico alto colombiano. Se han realizado investigaciones en prácticas de recuperación de suelos y renovación de praderas para mejorar la productividad de la biomasa forrajera. Recientemente, se evaluó el crecimiento de especies forrajeras en diferentes condiciones ambientales, para generar esquemas de manejo eficientes. En 2018 se registró un cultivar de avena forrajera Altoandina, pero, existe una limitada oferta de forrajes, debido a la ausencia de programas de mejoramiento y evaluación de germoplasma. Se ha generado información respecto al manejo integrado de la chinche de los pastos Collaria scenica. En sistemas silvopastoriles (SSP) se ha realizado la caracterización y utilización de especies arbóreas y arbustivas. En los sistemas de alimentación se ha realizado el reconocimiento composicional de los recursos alimenticios y el diseño de esquemas de suplementación que mejoren la respuesta animal. Se concluye que la 
producción de metano incrementa a medida que las especies forrajeras presentan mayor madurez, además, una dieta balanceada reduce las emisiones de metano, incluyendo los SSPs. Finalmente, los desarrollos de investigación deben incorporar y reconocer los costos de producción del sistema, para asegurar la adopción de las tecnologías desarrolladas.

Palabras clave: costos de producción; ganado de leche; manejo de pastoreo; producción forrajera; sistemas silvopastoriles.

\section{INTRODUCTION}

Nowadays, the increase in the demand for animal protein, due to population growth, is a challenge for the sustainability of anthropogenic activities (Gerber et al., 2013). In this sense, to develop sustainable animal production systems that promote intensification, reduce the impact on the environment and maintain the quality of life of the rural population (Makkar, 2016). In Colombia, milk production is a main activity in the agricultural sector because it guarantees food security and food sovereignty. Besides, within products of animal origin, milk generates the lowest greenhouse gas emissions per unit of product, which, gives it importance in the framework of the development of sustainable animal production systems (Gerber et al., 2013).

Production and consumption of milk in the world is led by the United States, but, New Zealand is the country with the highest participation to milk powder exports. Brazil leads the production and consumption of milk in South America; however, Colombia shows growth in milk production in recent decades (2.4\% annually), making it necessary to develop sustainable intensification schemes for this activity (Espinal et al., 2005; CNL, 2010). Despite this growth, Colombia has high production costs and low milk productivity (Conpes, 2010), due to a high investment in feeding supplementation and grassland management (ACLácteos, 2017).

In 2016, the bovine inventory in Colombia was 27.2 million animals, distributed in 623,794 farms (DANE, 2016). Milk production in Colombia in 2018 was 7,257 million liters (Fedegan, 2019), of which, between 45 and $52 \%$ comes from specialized dairy systems (Corpoica, 2005; Cardozo, 2008). The fate of dairy production is $41.3 \%$ for industry, $35 \%$ for intermediaries and 20\% for self-consumption. This activity represents $24.3 \%$ of livestock GDP and generates 633,647 direct jobs. Finally, the national per-capita milk consumption was 143 liters during 2019 (Fedegan, 2019).

Most milk production systems belongs to smallholders. In this sense, $66 \%$ of the productive units have less than eight cows. Besides, low animal productivity (4.8 liters per animal day, average) is evident compared to other countries in the region. Cundinamarca participates with $20 \%$ of the national dairy production, followed by Antioquía and Boyacá with 12 and 10\%, respectively (CNL, 2010).

Feeding systems of dairy cows are mainly supported on pastures and strongly influenced by environmental conditions. Animal productivity increases in periods of high precipitation, associated with higher production of dry matter (DM), and animal productivity decreases with drought (Corpoica, 2005; Gachetá et al., 2016). The pastures, in high tropic, are located on 6 million hectares in the departments of Cundinamarca, Boyacá, Antioquia and Nariño. This area concentrates $87 \%$ of the country's specialized dairy farms (Cardozo, 2008; Santana et al., 2013).

Milk production systems in Colombia have a variety of cost structures, however, for specialized milk production systems, items associated with labour (26.9\%), feeding (37.0\%) and forage management (7.4\%) have great impact in cost structure (Espinal et al., 2005; Cardozo, 2008; FEDEGAN 
et al., 2013). In Colombia, production costs are higher than countries with high efficiency (CLA, 2001). For example, Corpoica (2005) reported that production costs were US\$ 0.16 per liter, presenting a higher value (US\$ 0.21) in specialized dairy farms, during 1998. Besides, the price of milk is associated with the climate, showing higher prices in dry seasons and lower in rainy seasons (Espinal et al., 2005). Besides, production and marketing of milk are very fluctuating because milk is a perishable product and marketing channels are limited (CLA, 2001).

Soil recovery and chemical fertilization. Studies of soils in specialized dairy production systems have not presented enough historical interest when considering a static component or with an unknown relationship for milk production. However, soil degradation processes result in a decrease in dry matter (DM) production and milk production, generating the need to identify the current state of the soils and carry out interventions physical, chemical and biological. To carry out these interventions, Gachetá et al. (2016) developed a guide that describes how to take and send soil samples to certified laboratories. Also, the literature describes the methodology for interpreting the soil analysis and generating the recommendations that allow replacing nutrient deficiencies (Corpoica, 2011a; Gachetá et al., 2016).

Corpoica (now Agrosavia) has made researches on pastures in Colombian high tropic seeking for alternatives that reduce soil degradation processes, the seasonality of production and the low offer of forages (Corpoica, 2011a). In this sense, studies have been focused on recovering and renewing of grasslands and evaluation, establishment and management of grazing forages and the production of forage crops for ruminant feed systems.

Regarding the renovation of pastures, Mila and Corredor (2004) evaluated the botanical composition of Kikuyu grassland after making different mechanization process like i) brushcutter, ii) Vertical tillage (renovator), iii) harrow, iv) brushcutter + renovator and v) brushcutter + renovator + harrow. This experiment evaluated three levels of composting application ( 0,300 and $600 \mathrm{~kg} / \mathrm{ha}$ ). The renovation increased kikuyu's coverage by $20 \%$ and reduced the coverage of other grasses (10\%), legumes (2\%) and weeds (10\%). Arrieta (2004) observed that renewal of pastures reduces up to $23 \%$ the weed population, considering this practice like a strategy to reduce the proportion of weeds. However, the effect of this practice on desirable species such as legumes and herbaceous is evaluated.

Other studies observed that renewal of pastures increased biomass production in 92\%, besides milk production per hectare increased and farm's animal carrying capacity doubled, due to the presence of ryegrass and clovers in the pasture. Also, increased crude protein percentage of the forage (10\%) and decreased rotation days (50\%) (Sánchez and Villaneda, 2007). Báez et al. (2003) emphasized the need to frequently monitor the physical, chemical and biological characteristics of the soil to establish a scheme for fertilization, grassland renewal and pest and diseases control, which promotes productivity of milk farms.

To improve the quality and production in pastures, since 2003, Corpoica carried out research aimed at recovering degraded soils according to physical parameters such as: density, porosity, retention of humidity, structural stability, infiltration and resistance to penetration. Generating appropriate recommendations for soil mechanization processes (Báez et al., 2003).

Studies carried out by Cuesta (2005) and Sánchez (2007), report degraded soils in the dairy systems of the high tropics. The penetration resistance presented values higher than 1 Megapascal (Mpa) and high micropore levels (>35\%). Soil degradation 
affected radical development, the activity of flora and fauna of soils, anchorage of vegetal species and structural stability with particles smaller than $1 \mathrm{~mm}$. Besides the area to capture nutrients and water decreased. The pasture productivity decrease affects the profitability of production systems. In this sense, Sánchez et al. (2013) mention that vertical mechanization practices improve the physical conditions of the soil and increase productivity between 17.3 and 48\%.

Programs for evaluating the productive response of forages to different fertilization protocols were developed until the 1970s, resulting in recommendations for Colombian high tropic grasses. That protocols recommend between 400-600 kg N.ha-1, 150-300 kg. $\mathrm{P}_{2} \mathrm{O}_{5} \mathrm{ha}^{-1}$ and 200-400 $\mathrm{kgK}_{2} 0 . \mathrm{ha}^{-1}$ (ICA, 1992). However, no fertilization schemes are reported for new varieties with higher biomass productions in varying environmental conditions (Vargas et al., 2018).

Improving soil quality increases the profitability of the system, but, is necessary to do several chemical, physical and biological studies, especially in the application effect of amendments, organic and chemical schemes of fertilization and soil structure. In the Cundiboyacense region the use of nitrogen fertilizers, together with irrigation, increase productivity of dairy farms, but increases production costs, that's why it is necessary to determine the economic response of $\mathrm{N}$ application (Holmann et al., 2003). Also, macronutrient and micronutrient requirements of forages used in Colombian high tropics in contrasting environmental conditions should be evaluated. Finally, it is necessary to update management recommendations for species that have the high grow potential and intensive grassland management schemes.

Forage resources and grazing management. Few studies have evaluated forages in Colombian high tropics, recently. Agrosavia obtained the registration of Alto Andina oat cultivar as a supplementation strategy for dairy production systems in the Andean region, Cundiboyacense highlands and Nariño plateau. Corpoica (2011a) measured the response, among others, of ryegrass, Kikuyu, clover, lotus, wheat and barley in different locations of the Colombian high tropics, recognizing differences between the materials evaluated. On the other hand, Vargas et al. (2018) found no differences during establishment and production phase of diploid and tetraploid ryegrasses in two regions of Colombian high tropics. In this same work, these authors mention that white clover, unlike the red clover, disappeared in the locality that presented less precipitation. Besides, Posada et al. (2013) evaluated diploid and tetraploid intercropping ryegrasses in a Kikuyu pasture, finding a better response for diploid ryegrass, possibly due to a lower nutrient requirement. These studies suggest that agro-ecological conditions modulate the productive response of forages, suggesting that it is necessary to evaluate these especies in specific microregions under different environments (Corpoica, 2011b; Corpoica, 2012; Vargas et al., 2018).

Regarding pests, Corpoica (2016c) generated a recommendation for integrated management of the pasture bedbug (Collaria scenica (Hemiptera: Miridae)), in which emphasizes in the proper pasture and pesticides management. On the other hand, Posada-Florez et al. (2014) reported that there may be moderate damage (31.3\%) in Kikuyu grass by the aphid (Sipha flava), observing yellowing in the basal part of the plant; however, these researchers do not mention how this insect affects the quality of Kikuyu grass.

Likewise, Arango et al. (2017) carried out a morphological study of Kikuyu grass in seven municipalities of the department of Antioquia at different altitudes, reporting that Kikuyu 
pasture has high morphological variation, due his plasticity, and no pattern of similarity or dissimilarity was found in his morphology per the municipality,. Moreover, altitude has effects in some morphological traits. Agrosavia (2019) evaluated the morphology of Kikuyu grass in six municipalities on the Andean region. In this study, it was found high morphological variation in this pasture, this result promoted a genetic diversity study in six departments of Colombia.

Management of grasslands allows optimizing the use of forage and animal production. In this context, Cuesta (2005) reported that defoliation understood as the removal of aerial part of plants, is the main effect caused by the animal on the grassland and defines its productivity, according to accumulated reserve nutrients in a period. Further, Arreaza et al. (2005a) mention that proper management of the grassland requires the incorporation of some concepts such as rest and occupation periods, grazing pressure and carrying capacity, which allows maximizing the production of good quality biomass throughout the year.

In Colombian high tropic biomass production is not constant and depends on management practices and environmental conditions in each production system. In this sense, Corpoica (2016a) and Vargas et al. (2018) reported differences in the production of biomass of Kikuyu and ryegrass in different dairy regions of the Colombian high tropics (Table 1). Fonseca et al. (2016) mentioned growth rates of Kikuyu grass that ranged between 75.4 and $95.3 \mathrm{~kg}$ DM ha ${ }^{-1} \mathrm{~d}^{-1}$. Besides, recent research conducted by Corpoica (2017) reported in Altiplano Cundiboyacense show lowest growth rates of Kikuyu grass in Cucunubá (5kg DM.ha$\left.{ }^{1} \cdot \mathrm{d}^{-1}\right)$ and the highest growth rate was reported in Mosquera (150kg DM.ha-1. $\mathrm{d}^{-1}$ ). These results imply differential grassland management schemes between seasons and regions.

Arreaza et al. (2005a) and Arreaza et al. (2005b) generated an expert prairie management software or Manejo Experto de Praderas, MEP-2®, which estimates dry matter intake (DM) from biomass digestibility, crude protein concentration, soluble carbohydrates and fractions of fibre. In this sense, carrying capacity for animals depends on occupation and rest periods and availability of forage. This software was validated, and it was determined that there is a low correlation between predicted dry matter intake and the composition of the forage. Besides, a better adjustment was presented during the rainy period concerning drought period. Developments like this should continue to generate tools that allow the producer to make right decisions.

Table 1. Maximum growth rates (kg DM/ha/d) of forage in rainy season (R) and drought (D) present in specialized dairy production systems in high Colombian tropics.

\begin{tabular}{|c|c|c|c|c|c|c|c|c|c|}
\hline \multirow[t]{2}{*}{ Species } & \multicolumn{2}{|c|}{$\begin{array}{c}\text { Ubaté- } \\
\text { Chiquinquirá }\end{array}$} & \multicolumn{2}{|c|}{$\begin{array}{c}\text { Alto } \\
\text { Chicamocha }\end{array}$} & \multicolumn{2}{|c|}{$\begin{array}{c}\text { Sabana de } \\
\text { Bogotá }\end{array}$} & \multicolumn{2}{|c|}{$\begin{array}{c}\text { Altiplano } \\
\text { Nariñense }\end{array}$} & \multirow[t]{2}{*}{ Source } \\
\hline & $\mathbf{R}^{1}$ & $\mathrm{D}^{2}$ & $\mathbf{R}$ & D & $\mathbf{R}$ & D & $\mathbf{R}$ & D & \\
\hline Kikuyu & 144,2 & 57,9 & 144,2 & 31,2 & 79,2 & 28,7 & 47,7 & 25,5 & Corpoica, 2016a \\
\hline Ryegrass & & & 70,1 & 38,8 & 54,3 & 41,9 & 90,2 & 65,3 & Corpoica, 2016a \\
\hline Ryegrass & & & \multicolumn{2}{|c|}{77,8} & \multicolumn{2}{|c|}{20,6} & & & Vargas et al., 2018 \\
\hline Clover & & & \multicolumn{2}{|c|}{44,1} & \multicolumn{2}{|c|}{43} & & & Vargas et al., 2018 \\
\hline
\end{tabular}

$\mathrm{R}^{1}$ : Rainy season; $\mathrm{D}^{2}$ : Drought season. 
In Colombia, there is not a vegetal germplasm selection and evaluation programs for ruminant feeding systems for high tropic. One strategy is to generate alliances with research centres, academy and commercial distributors. To increase milk production and impact on higher economic income in farmers. Also, knowledge of native and naturalized species that are more resilient to environmental offerings in the Colombian upper tropics should be promoted. Finally, the generation of information systems should be encouraged to explain and predict the productive response and allow better management of the grasslands.

Silvopastoral Systems. Silvopastoral Systems (SSPs) are an alternative for the milk production system in the high tropic. SSPs offers quantity and quality of forage, animal welfare, improves the quality of soils, provides solutions to environmental problems and contributes to the application of agro-ecological principles. Agrosavia, CIPAV and some universities have started research to offer feeding alternatives to milk farmers in Colombian high tropics. The main species research ananalyzed SSPs are bushes i) Sambucus peruviana (Corpoica, 2015) ii) Sambucus nigra L. (Carvajal et al., 2012) iii) Tithonia diversifolia (Hemsl.) Gray iv) Morus alba L. and v) Trichanthera gigantea (Humboldt \& Bonpland) Nees, and some arboreal trees i) Montanoa quadrangularis Sch.Bip. ii) Alnus acuminata Kunth (Naranjo and Cuartas, 2011) iii) Acacia decurrens Willd. (Quiceno and Medina, 2006). Besides, Sánchez et al. (2009) observed that incorporated, in the diet, Alnus acuminata Kunth increased forage production (53\%), live material (23\%), the life/dead forage ratio (85\%), carrying capacity $(100 \%)$, crude protein $(23 \%)$ and reduces the content of the lowest-available protein fraction (30 - 50\%). These results are associated with higher production per unit area and higher system profitability. However, these authors mention the need to assess a greater variety of shrub and tree to reduce establishment periods, production costs, increase carbon capture and resilience of pastoral systems. The research has been focused on the use and characterization of these species, but there is still research on issues such as economic evaluation, environmental impact, establishment, fertilization, pests and animal diseases and welfare, among others.

In silvopastoral systems, Corpoica (2015) presented the chemical composition of Sambucus peruviana to Cundiboyacense region, Carvajal et al. (2012) Sambucus nigra L and Acacia melanoxylon to Bogotá savannah, finally Naranjo and Cuartas (2011) in Antioquia, presented the chemical composition of some shrub and arboreal species that can be used in the Colombian high tropics (Table 2).

Table 2. Chemical composition (\% DM) of resources of tree and shrub species with potential for food in dairy farming systems in the high Colombian tropics.

\begin{tabular}{|c|c|c|c|}
\hline Resource & CP & NDF & ADF \\
\hline Sambucus peruviana & 24.10 & 29.4 & 9.91 \\
\hline Acacia decurrens Willd & 14.1 & 55.1 & 26.5 \\
\hline Sambucus nigra L. & 19.4 & 37.4 & 15.7 \\
\hline Alnus acuminata Kunth & 16.9 & 35.8 & 31.1 \\
\hline $\begin{array}{l}\text { Tithonia diversifolia } \\
\text { (Hemsl.) Gray }\end{array}$ & 24.1 & 38.6 & 33.7 \\
\hline Morus alba L & 24.8 & 33.6 & 32.7 \\
\hline $\begin{array}{l}\text { Trichanthera gigantea } \\
\text { gigantea (Humboldt \& } \\
\text { Bonpland) Nees, }\end{array}$ & 21.2 & 43.7 & 41.7 \\
\hline $\begin{array}{l}\text { Montanoa quadrangularis } \\
\text { Sch.Bip }\end{array}$ & 26.3 & 43.9 & 33.7 \\
\hline
\end{tabular}


Nutrition and feed. Description of the chemical composition of feed sources available in high tropic to generate feeding systems that meet the nutritional requirements of the animals of different age groups is required. Corpoica (2013) presented the chemical composition of food resources most used in specialized dairy farms in the Colombian high tropics (Table 3).

Table 3. Chemical composition (\% DM) of feed resources used in dairy farming systems in the high Colombian tropics.

\begin{tabular}{|c|c|c|c|c|c|c|c|}
\hline Feedstuff & $\mathrm{CP}$ & NDF & ADF & EE & NSC & $\mathrm{Ca}$ & $\mathbf{P}$ \\
\hline & \multicolumn{7}{|c|}{ Grazing forages } \\
\hline Kikuyu & 17.3 & 63.1 & 28.7 & 2.7 & 3.6 & 0.42 & 0.49 \\
\hline Kikuyu + ryegrass & 19.5 & 59.2 & 27.1 & 3.4 & 5.3 & 0.58 & 0.45 \\
\hline \multirow[t]{2}{*}{ Ryegrass } & 22.2 & 50.1 & 24.2 & 4.2 & 6.8 & 0.73 & 0.46 \\
\hline & \multicolumn{7}{|c|}{ Forage cutting and carry } \\
\hline Lucerne & 25.1 & 46.9 & 31.2 & 2.9 & 8.4 & 1.5 & 0.5 \\
\hline Brazilian grass & 22.8 & 59.0 & 27.8 & 2.3 & 4.5 & 0.5 & 0.5 \\
\hline \multirow[t]{2}{*}{ Forage beet } & 16.1 & 38.7 & 9.9 & 1.2 & 9.6 & 1.5 & 0.1 \\
\hline & \multicolumn{7}{|c|}{ Preserved forages } \\
\hline Oat silage & 12.1 & 66.5 & 37.8 & 2.1 & 12.3 & 0.48 & 0.34 \\
\hline Corn silage & 9.1 & 60.1 & 34.0 & 2.9 & 15.3 & 0.69 & 0.34 \\
\hline Angleton hay & 3.6 & 79.9 & 48.0 & 1.7 & 2.1 & 0.09 & 0.22 \\
\hline \multirow[t]{2}{*}{ Kikuyu haylage } & 15.4 & 68.5 & 31.0 & 2.9 & 2.9 & 0.61 & 0.51 \\
\hline & \multicolumn{7}{|c|}{ Raw feed stuffs } \\
\hline Brewers grains & 28.5 & 38.6 & 20.2 & 10.4 & 30.1 & 0.26 & 0.56 \\
\hline Distiller's Grains with S & 31.1 & 43.2 & 3.8 & 4.6 & 11.3 & 0.32 & 1.4 \\
\hline Malt germ & 24.2 & 42.0 & 19.1 & 0.6 & 1.1 & 0.26 & 0.52 \\
\hline Barley grain & 12.7 & 30.1 & 9.0 & 2.9 & 53.2 & 0.07 & 0.39 \\
\hline Wheat grain & 13.7 & 27.5 & 10.2 & 3.1 & 35.7 & 0.06 & 0.39 \\
\hline Corn grain & 8.4 & 9.3 & 2.8 & 3.0 & 70.2 & 0.03 & 0.27 \\
\hline Palm kernel & 14.2 & 81.7 & 26.2 & 3.4 & 24.8 & 0.25 & 0.59 \\
\hline Cotton seed & 19.3 & 46.9 & 27.0 & 17.2 & 9.1 & 0.16 & 0.62 \\
\hline Soybean extruded & 40.0 & 12.0 & 7.1 & 8.6 & 10.2 & 0.35 & 0.62 \\
\hline Cotton cake & 35.3 & 45.1 & 28.0 & 0.6 & 14.8 & 0.23 & 1.4 \\
\hline Soybean meal & 55.5 & 13.4 & 3.2 & 13.3 & 19.8 & 0.40 & 0.72 \\
\hline
\end{tabular}


Traditionally, compositional analyses of the feedstuff's resources destined to the feeding of ruminants have been developed through destructive methods (Van Soest, 1991; AOAC, 2005). However, Vásquez et al. (2004) mentioned how the near-infrared methodology allows describing the chemical composition of Guinea grass and corn. This methodology predicted with precision DM, ether extract, ashes, crude protein, neutral detergent fibre, neutral detergent acid and in vitro digestibility of DM, but not for the non-structural carbohydrates and non-protein nitrogen. Recently, Ariza et al. (2017) adjusted the equations to predict the composition of 13 nutrients, product of the analysis of 4737 grass, 677 legumes and 419 trees.

One of the main problems to specialized dairy farms in high tropics is a low level of DM of forages available in the grassland, due to the characteristics of the forages, high levels of fertilization and environmental conditions. Water concentration in forages has an inverse relationship concerning voluntary consumption, which, is restricted due to the volume of material. In this sense, Sánchez (2007) found that DM content of available forage in grassland varied between 12.6 and $25.4 \%$ as rest period increased from 42 to 73 days, respectively. In this sense, the availability of DM presented values that ranged between 13.1 to $25.5 \mathrm{~kg} \mathrm{DM} /$ cow/day, relatively low when compared with those suggested by the literature $(25$ to $40 \mathrm{~kg}$ DM/cow/day, Bargo et al., 2003). Therefore, implement strategies to optimize the management of grasslands are necessary to guarantee adequate DM intake and nutrients, according to the state of lactation and the productive level of the cows.

In Colombian high tropics, the nitrogen levels in grasslands are higher, due to the high application doses, and short regrowth days. Also, low levels of non-structural carbohydrates and inadequate levels of energy supplementation increase ammoniacal nitrogen levels in rumen and energy requirements of the animal, due to urea synthesis processes, which increases nitrogen excretion in milk and urine, and contaminates in soils and waters. Sánchez (2007) found that levels of milk urea nitrogen (MUN) on different farms, were higher than $18 \mathrm{mg} \mathrm{dl}^{-1}$, indicating excess of soluble nitrogen and/or fermentable energy deficiency in the diet. Therefore, it is necessary to evaluate different supplements and levels of inclusion that allow the proper use of nutrients, optimizing the production and quality of the final product. Sánchez (2007) reported the concentration of crude protein, soluble protein and cell wall of forages from different dairy regions in the high Colombian tropics (Table 4).

Table 4. Nutritional quality of grasslands of specialized dairy farms in high tropics (Sánchez, 2007).

\begin{tabular}{lccc}
\hline \multirow{2}{*}{ Regions } & \multicolumn{3}{c}{ Nutritional Quality Indicators } \\
\cline { 2 - 4 } & $\begin{array}{c}\text { Crude Protein } \\
\text { (\% DM) }\end{array}$ & $\begin{array}{c}\text { Soluble Protein } \\
\text { (\% CP) }\end{array}$ & $\begin{array}{c}\text { Cell Wall } \\
\text { (\% DM) }\end{array}$ \\
\hline Antioquia & $14.3-22.4$ & $35.5-43.5$ & $51.4-58.9$ \\
Ubaté-Chiquinquirá & $15.2-23.3$ & $38.7-44.1$ & $53.7-59.7$ \\
Sabana de Bogotá & $13.6-21.4$ & $32.8-42.0$ & $53.5-67.8$ \\
Alto Chicamocha & $15.2-19.6$ & $31.4-43.4$ & $55.9-60.1$ \\
Nariño & $12.1-16.5$ & $35.6-37.8$ & $43.7-49.8$ \\
\hline
\end{tabular}


The study carried out on ruminant feeding systems has focused on the evaluation of supplementation strategies to increase nutritional efficiency. In this sense, Corpoica (2016b) evaluated in four farms the supplementation with diets formulated at minimum cost and with low protein content, according to the nutritional requirements of the animals. Results showed that supplementation reduced MUN concentrations and supplementation costs and did not change production and dairy compositional quality.

Supplementation studies developed by the Colombian Agricultural Research Corporation (Agrosavia), has used glycerine as a strategic feedstuff for bovine feeding systems, given the high energy value (1.9-2.2Mcal $\mathrm{NE}_{\mathrm{L}} / \mathrm{kg} \mathrm{DM}$, depending on the concentration of glycerol) and the low cost, compared to maize (about 80\%). In a trial, with cows, it was observed that supplementation during early lactation showed a tendency to increase accumulative milk production when 300 or $500 \mathrm{~g}$ of glycerine/cow/day were applied (Corpoica, 2009). Other supplementation exercises, glycerine has been included up to $30 \%$, favouring homogenization and palatability, besides, the presence of microparticles decreased and the low cost of the supplement has been achieved, the above by the replacement of other sources of carbohydrates, such as corn, sorgo or barley of higher price and difficulty to buy (Corpoica, 2016b).

On the other hand, López and Saavedra (2010) evaluated the supplementation with oat silage and oat silage + supplement (energy: protein) compared to a conventional diet. These authors found no differences between treatments in terms of individual milk production, however, supplementation increasing carrying capacity and production per hectare. On the other hand, Corpoica (2011c) observed that replacing pastures with oat silage increased the net profit per litre of milk between 0.6 and $85 \%$.
Through simulation exercises and using the Cornell Net Carbohydrate and Protein System requirements estimation model (Fox et al., 2004), concluded that specialized dairy systems require higher content of energy ingredients or good quality silages (Cardozo, 2008). In this sense, Blanco et al. (2005) mention that silo enriched with molasses improved the in vitro digestibility of DM and is the one that presented the best simulated productive response regarding formic acid use.

The nutrition ruminant's evaluations are focusing on a cases study approach. In this sense, it is necessary to develop programs that recognize the individual characteristics, how the determination of requirements, the definition of DM consumption, differentiation between physiological states, hierarchical behaviours, that are associated with the animal response. Also, it is necessary to know the own food resources and sub products of the region with potential for use in ruminant feed systems. Is important to emphasize the need to determine the costs of interventions to develop technology profitable for the farmer. Finally, the instrumentalization and the acquisition of equipment that allow better the feeding systems and related them with the profitability of the production system should strengthen.

Emission of greenhouse gases. Milk production systems, based on the consumption of Kikuyu grass, have a higher efficiency of energy use, as demonstrated by Noguera and Posada (2017), since the value of Ym, that represented loss of GE as methane was $4.9 \%$, compared to a $6.5 \%$ standard.

Applied research that seeks to reduce methane emissions in ruminants for the high tropics of Colombian are few. In general, studies show that the greater the maturity of the forage species, the production of $\mathrm{CH}_{4}$ increases and, on the other hand, the association of grasses with legumes presents less methane gas production. In a research carried out in 
Antioquia, Marín (2013), concluded that methane emissions, product of in vitro ruminal fermentation, are directly related to the nutritional quality of Kikuyu grass and the proportion of supplement in the diet. Also, mixing Kikuyu with ryegrass improved tends to increase the degradation of Kikuyu grass (Restrepo, 2016). However, the degradation leads to increased production of methane gas. Also, grasses with less content of structural carbohydrates, such as ryegrass amson, generate less methane emission (Apráez-Guerrero et al., 2016), indicating that proper management of grasslands can reduce methane emission (Apráez et al., 2014).

Some studies have evaluated the effect of additive consumption to reduce methane emissions. In that sense, Angarita (2007) reports a reduction in methane in rations included containing coconut oil, which shows that there are several strategies to mitigate the effect of methane on dairy systems.

Research to determine methane emissions in milk production systems of the high tropics indicates that the improvement in the forage offer with renewal grassland or silvopastoral systems makes a reduction in the emissions of this greenhouse gas (Silva et al., 2013). However, Donney's (2015), evaluating the consumption of gold button, found that the silvopastoral system promotes the consumption of dry matter, but does not help to reduce methane emissions.

Recently, Avellaneda et al. (2018), evaluated the measurement of enteric methane through the SF6 methodology, comparing a commercial supplementation and supplementation designed for the production system and methane production. They show not differences between treatments, but, the supplement commercial presented a higher production of methane, respect to supplementation designed for the system.

Production costs. The research carried out in specialized dairy production systems has mainly been developed around the technical components, however, the socioeconomic component is a fundamental axis, to processes effective of technology adoption (Corpoica, 2005). In this sense, the production costs are related according to expectations of each family or companies, markets demand and access to means of production. That is why recognizing the costs of production and distribution of the items within the different activities is a strategy that would increase the competitiveness and profitability of dairy systems specialized in Colombian high tropics (CLA, 2001).

The dairy chain of Antioquía (CLA, 2001) evaluated production costs in specialized dairy systems in Antioquía. $73,4 \%$ of farmers had less than 34 ha, which, $53 \%$ produced between 11 and 15 thousand $\mathrm{L} / \mathrm{ha} / \mathrm{y}$, suggesting cost-effective system, while $45 \%$ produced less than $10 \mathrm{mil} \mathrm{L} / \mathrm{ha} / \mathrm{y}$, possibly generating losses. Besides, higher productivity in dairy systems was associated with a greater proportion of costs focusing on feeding and forage management. Another hand, Santana et al. (2013) selected modal farms in the four dairy basins of Colombia and reported that food (37\%) and labour (25\%) were the items with the highest participation in the cost structure. The highest costs per litre of milk were determined in Antioquia, followed by Cundiboyacense highlands and the lowest in Nariño. Largest milk production was presented in the Cundiboyacense highlands, followed by Antioquia and Nariño. Finally, these authors mentioned a productivity of $7.04,5.31$ and $3.37 \mathrm{~L} / \mathrm{ha} / \mathrm{y}$ for large, medium and small producers, respectively, suggesting a technological gap between producers.

Other authors have evaluated production costs by comparing systems with high and low technological development. In this regards, Gómez-Jurado and Castillo (1997) determined that 28.53 and $43.45 \%$ of the costs were represented in capital investments for systems with low and high technological development, respectively. The animal component 
constituted 42.3 and $60.7 \%$, for low and high technological development, respectively, with labour and food being the most important items. Finally, in systems with lowtechnological development, the gross margin per litre was 6\% higher, although, the productive parameters and the cost-benefit ratio was $0.3 \%$ lower, respect to systems with better technological development.

Cardozo (2008) carried out the analysis of the costs of production systems to which pasture renewal processes were carried out, with an horizon of 20 years and assuming that the renewal of pasture increased $10 \%$ of dairy production. These authors reported that traditional systems located in Alto Chicamocha have higher profitability compared with Ubaté, Antioquia and Nariño. In Nariño dairy systems were not profitable, when implementing pasture renewal processes Land items (13$22 \%)$, infrastructure (11-23\%), labour (6-14\%), supplements ( 11 to $24 \%$ ) and pastures ( 6 to $26 \%$ ) presented a higher proportion in the cost structure of the systems evaluated.

Cardozo (2008) suggested that the low profitability of specialized dairy systems is due to improper feeding and feed management practices. Added to this, Santana et al. (2013) mention that the absence of the management of the dynamics of the animal population, the limited schooling and the low business vision of the producers have limited the development of the dairy production system. The CLA (2001) mentioned that the small scale of production, the limited access to technology, the high cost of land and the low control of milk prices, are limiting the profitability of production systems.

\section{CONCLUSIONS}

Generally, research to feeding systems for the Colombian highlands tend to a systematic approach, however, it is necessary to expand making these studies to identify and characterize with greater detail the variation in the productive expression of native forage, shrub and tree species; and generate a breeding plants species program in Colombian high tropic. On the other hand, it is convenient to research fertilization plans that include minerals, application times and economically viable in different ecoregions to improve the management of forage resources and the economic efficiency of productive systems. Finally, to mitigate the effect of greenhouse gases is necessary promote programs for the association of legume and SSP, to improve the competitiveness and sustainability of dairy systems in Colombian high tropics.

Research in bovine feeding systems for the high tropics must be immersed in an efficient dairy production model. farmers, academy and commercial allies must actively participate in research needs to develop efficient and sustainable production strategies, to generate recommendations for technological options that strengthen the dairy sector, not only in the high tropics but also throughout the country.

Conflict of interests. The authors declare that there is no conflict of interest.

\section{BIBLIOGRAPHIC REFERENCES}

AC-Lácteos. (2017). Informe técnico Misión 1.2. Actualización de la canasta de insumos ganaderos para producción de leche en Colombia. Colombia: Propaís. 84p.

Agrosavia - Corporación Colombiana de Investigación Agropecuaria. (2019). Informe técnico final. Incremento de la rentabilidad de los sistemas de producción de leche del trópico soportados en Kikuyo. Colombia: Agrosavia. 104p.

Angarita, E.A.; González, C. (2007) Efecto de la inclusión de aceite de coco sobre la producción de metano y parámetros de fermentación ruminal en novillas utilizando la técnica de túnel. Fusagasugá: Facultad de Zootecnia, Universidad de Cundinamarca. 120p. 
Apráez-Guerrero, J.E.; Delgado-Jurado, D.; SolartePortilla, C. (2016). Evaluación In vitro de la producción de metano en variedades de pastos neozelandeses del altiplano de Nariño. Veterinaria y Zootecnia. 10(2): 90-105.

Apráez, G.E.; Gálvez, C.A.; Jojoa, R.C. (2014). Valoración nutricional y emisión de algunos recursos forrajeros del trópico de altura. Revista de Ciencias Agrícolas. 31(1): 122-134.

Arango, G.J.; Cardona, N.F.A.; López, H.A.; Londoño, C.G.; Echeverry, Z.J.J. (2017). Variación de caracteres morfológicos del pasto Kikuyo (Cenchrus clandestinus) en el trópico alto de Antioquia. Revista de la facultad de Medicina Veterinaria y de Zootecnia. 12(1): 44:52. doi: http://dx.doi.org/10.21615/ cesmvz.12.1.4

Ariza, C.; Mayorga, O.L.; Mojica, B.; Parra, D.; Afanador, G. (2017). Use of LOCAL algorithm with near infrared spectroscopy in forage resources for grazing systems in Colombia. J. Near Infrared Spe. 26: 44-52. doi: https://doi.org/10.1177/0967033517746900

Arreaza, L.C.; Franco, A.; Mayorga, J.; Mateus, H.; Pardo, 0.; Sánchez, L.; Barros, J.; Pérez, O. (2005a). MEP-2®: Programa de computador para el manejo de praderas con bovino en el trópico colombiano. I. Desarrollo informático. Corpoica Cienc. Tecnol. Agropecuaria. 6(2): 14-20. doi: https://doi.org/10.21930/rcta. vol6_num2_art:43

Arreaza, L.C., Franco, A., Mayorga, J., Mateus, H., Pardo, 0., Sánchez, L., Barros, J.; Pérez, 0. (2005b). MEP2@: Programa de computador para el manejo de praderas con bovino en el trópico colombiano. II. Evaluación en campo del programa. Corpoica Cienc. Tecnol. Agropecuaria. 6(2): 21-27. doi: https://doi. org/10.21930/rcta.vol6_num2_art:44

Arrieta, J.M.(2004). Aspectos sobre el controlde malezas compuestas en pastos dedicados a la ganadería de leche. Corpoica Cienc. Tecnol. Agropecuaria. 5(1): 76-84. doi: https://doi.org/10.21930/rcta.vol5 num1_art:29

AOAC - Association of Official Agricultural Chemists. (2005). Official methods of analysis. $18^{\text {th }}$ Edition. AOAC International. Washington, USA: AOAC.

Avellaneda, Y.; Vargas, J.; Mayorga, 0. (2018). Un Modelo de balanceo de raciones validado para el manejo eficiente de forrajes en sistemas de producción de lechería especializada. Bogotá, Colombia: Corpoica. $27 \mathrm{p}$.
Báez, F.; Ruiz, H.; Ojeda, H. (2003). Problemática y estrategias para la renovación de praderas degradadas en sistemas de producción de leche del trópico alto de Nariño. Bogotá, Colombia: Corporación Colombiana de Investigación Agropecuaria (Corpoica), Federación de Ganaderos (FEDEGAN). 24p.

Bargo, F.; Muller, L.D.; Volver, E.S.; Delahoy, J.E. (2003). Production and digestion of supplemented dairy cows on pasture.J. Dairy Sci.86(1): 1-42. doi: https:// doi.org/10.3168/jds.S0022-0302(03)73581-4

Blanco, G.M.; Chamorro, D.R.; Arreaza, L.C. (2005). Predicción de la respuesta en bovinos lecheros suplementados con ensilaje de Sambucus peruviana, Acacia decurrens y Avena sativa usando el modelo Cornell Net Carbohydrate and Protein System (CNCPS). Corpoica Cienc. Tecnol. Agropecuaria. 6(2): 86-90. doi: https://doi.org/10.21930/rcta.vol6_ num2_art:53

Cardozo, F. (2008). Uso óptimo de insumos y modernas herramientas de costeo: Estrategias para la competitividad de la lechería especializada del trópico alto colombiano. Corporación Colombiana de Investigación Agropecuaria Corpoica). Bogotá, Colombia: Produmedios. 106p.

Carvajal, T.; Lamela, L.; Cuesta, A. (2012). Evaluación de las arbóreas Sambucus nigra y Acacia decurrens como suplemento para vacas lecheras en la Sabana de Bogotá, Colombia. Pastos y forrajes. 35(4): 417 430 .

CLA - Cadena Láctea de Antioquia. (2001) Acuerdo de competitividad de la cadena láctea de Antioquia. Colección Documentos IICA. Serie Competitividad No.20. Medellín, Colombia: Ministerio de Agricultura y Desarrollo Rural de Colombia y el Instituto Interamericano de Cooperación para la Agricultura, IICA. 116p.

CNL - Concejo Nacional Lácteo. (2010). Acuerdo de competitividad de la cadena láctea colombiana. Recovered from http://www.cnl.org.co/wp-content/files/AcuerdodeCompetitividadCadenaLactea2010.pdf

Conpes - Consejo Nacional de Política Económica y Social. (2010). Política nacional para mejorar la competitividad del sector lácteo colombiano. Recovered from https://www.minagricultura.gov. co/ministerio/direcciones/Documents/d.angie/ conpes\%203675.pdf 
Corpoica - Corporación Colombiana de Investigación Agropecuaria. (2017a). Informe técnico final. Recomendaciones de alimentación con base en un sistema de formulación de raciones (suplementosaditivos) en las fases de crecimiento, gestación y lactancia para mejorar la eficiencia productiva y reducir costos de producción de leche del trópico alto. Colombia: Corpoica. 76p.

Corpoica - Corporación Colombiana de Investigación Agropecuaria. (2017b). Informe técnico final. Desarrollo de estrategias para el fortalecimiento y soporte de la cadena de valor láctea de Colombia, basadas en las experiencias de Nueva Zelanda. Colombia: Corpoica. 53p.

Corpoica - Corporación Colombiana de Investigación Agropecuaria. (2016a). Informe técnico final. Base de datos con la información generada por las ecuaciones de predicción NIRS de recursos alimenticios para alimentación animal. Bogotá, Colombia: Corpoica. 76p.

Corpoica - Corporación Colombiana de Investigación Agropecuaria. (2016b). Informe técnico final. Una estrategia para suplementar vacas Holstein durante la lactancia para disminuir los costos de producción y mejorar la calidad de la leche. Bogotá, Colombia: Corpoica. 65p.

Corpoica - Corporación Colombiana de Investigación Agropecuaria. (2016c). Informe técnico final. Recomendación de Manejo Integrado de Plagas en la Chinche de los pastos, en sistemas de producción de leche para el Trópico Alto. Bogotá, Colombia: Corpoica. 15p.

Corpoica - Corporación Colombiana de Investigación Agropecuaria. (2015). Informe técnico final. Recomendaciones de manejo para cuatro especies forrajeras y un arreglo silvopastoril en sistemas de producción de leche del trópico alto (Corpoica). Bogotá, Colombia: Corpoica. 34 p.

Corpoica - Corporación Colombiana de Investigación Agropecuaria. (2013). Canasta de alimentos en ganadería bovina. Informe técnico final. Bogotá, Colombia: Corpoica. 45p.

Corpoica - Corporación Colombiana de Investigación Agropecuaria (2012). Informe técnico final. Tendencias de distribución de la chinche de los pastos Collaria scenica (Stal, 1859) Hemiptera: Heteroptera: Miridae en dos escenarios de tiempo para el Altiplano Cundiboyacense, Colombia. Bogotá, Colombia: Corpoica. 24 p.
Corpoica - Corporación Colombiana de investigación agropecuaria. (2011a). Informe técnico final. Valoración agronómica y productiva en fincas de nuevas gramíneas forrajeras adaptadas al medio para mejorar la competitividad de los sistemas de producción de leche especializada del trópico alto colombiano. Bogotá, Colombia: Corpoica. 149p.

Corpoica - Corporación Colombiana de Investigación Agropecuaria. (2011b). Plan estratégico de la red de pastos y forrajes. Red Ganadería y especies menores. Bogotá, Colombia: Corpoica. 48p.

Corpoica - Corporación Colombiana de Investigación Agropecuaria. (2011c). Informe Técnico Final. Estrategias de alimentación. Análisis económico de estrategias de alimentación y nutrición en los sistemas de producción de leche en el trópico de altura. crecimiento y alta productividad y calidad para la producción de ensilajes. Bogotá, Colombia: Corpoica. 73p.

Corpoica - Corporación Colombiana de Investigación Agropecuaria. (2009). Informe Técnico Final. Utilización de glicerina del biodiesel de palma africana (Elaeis guineensis) en sistemas de alimentación en vacas lecheras del trópico alto colombiano. Bogotá, Colombia: Corpoica. 96p.

Corpoica - Corporación Colombiana de Investigación Agropecuaria. (2005). Informe técnico final. Caracterización de los sistemas de producción de leche del trópico de altura en los departamentos de Boyacá y Cundinamarca. Bogotá, Colombia: Corpoica. 112p.

Cuesta, P. (2005). Fundamento de manejo de praderas para mejorar la productividad de la ganadería del trópico colombiano. Corpoica Cienc. Tecnol. Agropecuaria. 6(2): 5-13. doi: https://doi. org/10.21930/rcta.vol6_num2_art:42

DANE - Departamento Estadístico Nacional de Estadística. (2016). Encuesta Nacional Agropecuaria (ENA). Recovered from https://www.dane.gov.co/ index.php/estadisticas-por-tema/agropecuario/ encuesta-nacional-agropecuaria-enaa

Donney's, GV. (2015). Evaluación de las emisiones entéricas de metano en vacas lecheras bajo trópico alto con o sin la inclusión de botón de oro (Tithonia diversifolia). Recovered from http://bdigital.unal. edu.co/56288/1/1130639425.2017.pdf 
Espinal, C.F.; Martínez, H.J.; González, F.A. (2005). La cadena de lácteos en Colombia. Una mirada global de su estructura y dinámica (1991-2005). Documento de trabajo No. 74. Bogotá, Colombia: Ministerio de Agricultura y Desarrollo Rural - MINAGRICULTURA, Observatorio Agrocadenas. 36p.

Fedegan - Federación Colombiana de Ganaderos. (2019). Estadísticas, producción, producción y acopio de leche en Colombia. Recovered from https://www. fedegan.org.co/estadisticas/produccion-0

Fedegan - Federación Colombiana de Ganaderos, FNG - Fondo Nacional del Ganado \& SENA - Servicio Nacional de Aprendizaje. (2013). Costos modales en ganadería de leche - trópico alto de Colombia: Ventana a la competitividad ganadera. Oficina de investigaciones económicas.

Fonseca, C.; Balocchi, 0.; Keim, J.P.; Rodríguez, C. (2016). Efecto de la frecuencia de defoliación en el rendimiento y composición nutricional de Pennisetum clandestinum Hochst.ex Chiov. Agrosur. 44(3): 67 - 76. doi: 10.4206/agrosur.2016.v44n307

Fox, D.G.; Tedeschi, L.O.; Tylutki, T.P.; Ruseell, J.B.; Van Amburgh, M.E.; Chase, L.E.; Pell, A.N.; Overton, T.R. (2004). The Cornell Net Carbohydrate and Protein System model for evaluating herd nutrition and nutrient excretion. Anim. Feed Sci. Technol. 112: 29-78. doi: https://doi.org/10.1016/j. anifeedsci.2003.10.006

Gachetá, J.C.; Castillo, J. L.; Argüello, H. (2016). Manual de manejo integrado de praderas en Guatavita, Cundinamarca. 1ra edición. Bogotá, Colombia: Universidad Nacional de Colombia. 40p.

Gerber, P.J.; Steinfeld, H.; Henderson, B.; Mottet, A.; Opio, C.; Dijkman, J.; Falcucci, A.; Tempio, G. (2013). Tackling climate change through livestock - A global assessment of emissions and mitigation opportunities. Rome, Italy: Food and Agriculture organization of the United Nations (FA0). 139p.

Gómez-Jurado, H.; Castillo, T.S. (1997). Análisis Técnico Económico de dos modelos representativos del sistema de producción de leche en la Sabana de Bogotá. Programa regional Sistemas de producción. Regional Uno. Bogotá, Colombia: Corporación Colombiana de Investigación Agropecuaria (Corpoica). 23p.
Holmann, F.; Rivas, L.; Carulla, J.; Rivera, B.; Giraldo, L.; Guzman, S.; Martinez, M.; Medina, A.; Farrow, A. (2003). Evolución de los sistemas de producción de leche en el Trópico Latinoamericano y su interrelación en los mercados: un análisis del caso colombiano. Revista Carta Fedegan. 78: 51 - 62.

ICA - Instituto Colombiano Agropecuario. (1992). Fertilización en diversos cultivos. Quinta aproximación. Manual de asistencia técnica No. 25. Bogotá: ICA. 64p.

López, D.; Saavedra, G.F. (2010). Evaluación del efecto de la suplementación con ensilaje de avena y alimento balanceado a base de harina de cebada como estrategia para mejorar la competitividad y la sostenibilidad de los sistemas de producción de leche del trópico alto en condiciones de sequía. Tunja, Colombia: Universidad Pedagógica y Tecnológica de Colombia. 74p.

Makkar, H.P.S. (2016). Smart livestock feeding strategies for harvesting triple gain - the desired outcomes in planet, people and profit dimensions: a developing country perspective. Animal Production Science. 56(3): 519-534. doi: https://doi.org/10.1071/ AN15557

Marín, A. (2013). Estimación del inventario de emisiones de metano entérico de ganado lechero en el departamento de Antioquia, Colombia. Colombia: Universidad Nacional de Colombia, sede Medellín. 94p.

Mila, A.; Corredor, S. (2004). Evolución de la composición botánica de una pradera de kikuyo (Pennisetum clandestinum) recuperada mediante escarificación mecánica y fertilización con compost. Corpoica Cienc. Tecnol. Agropecuaria. 5(1): 70-75. doi: https://doi.org/10.21930/rcta.vol5_num1_ art:28

Naranjo, J.F.; Cuartas, C.A. (2011). Caracterización nutricional y de la cinética de degradación ruminal de algunos de los recursos forrajeros con potencial para la suplementación de rumiantes en el trópico alto de Colombia. Revista CES Med. Zootec. 6(1): 9-19.

Noguera, R.R.; Posada, S.L. (2017). Factor de emisión de metano entérico para vacas Holstein lactantes en la zona norte de Antioquia - Colombia. Livestock Research for Rural Development. 29(6). 
Posada-Florez, F. J.; Téllez-Farfan, L.; Simbaqueba, R.; Serna, F. (2014). Reconocimiento y observaciones bionómicas de sipha flava (hemiptera: aphididae) atacando el pasto Kikuyo en dos zonas de Colombia. Revista U.D.C.A. Atualidad \& Divulgación científica. 17(1): 99-145.

Posada, S.; Cerón, J.M.; Arenas, J.; Hamedt, J.F.; Alvarez, A. (2013). Evaluation of ryegrass (Lolium sp) establishment in kikuyo grass (Pennisetum clandestinum) paddocks using zero tillage. Revista CES Med. Zootec. 8(1): 26-35.

Quiceno, A.J.; Medina, S.M. (2006). La Acacia decurrens Will fuente potencial de biomasa nutritiva para la gandería del trópico de altura. Livestock research for rural development. 18(12).

Restrepo, C. (2016). Evaluación de diversas estrategias nutricionales para mitigar las emisiones de metano en ganadería de leche especializada. Colombia: Universidad de Antioquia. 131p

Sánchez, L.; Londoño, V.C.E.; Benavides, J.C.; Castillo, S.J.; Torres, D.R. (2013). Recuperación de suelos y renovación de praderas en sistemas de producción de leche especializada del trópico alto. Bogotá, Colombia: Corporación Colombiana de Investigación Agropecuaria (Corpoica). Ed. Produmedios. 54p.

Sánchez, L. (2007). Módulo Manejo de praderas y Nutrición animal. Informe Técnico Final del Proyecto Optimización de insumos y estrategias tecnológicas para el mejoramiento de la eficiencia productiva y económica en sistemas especializados de producción de leche en la Sabana de Bogotá, Valles de Ubaté y Chiquinquirá, Altiplano Norte de Antioquia, Altiplano de Nariño y Alto Chicamocha. Bogotá, Colombia: Corporación Colombiana de Investigación Agropecuaria (Corpoica). 37 p.

Sánchez, L.; Villaneda, E. (2007). Renovación y manejo de praderas en sistemas de producción de leche especializada en el trópico alto colombiano. Bogotá, Colombia: Corporación Colombiana de Investigación Agropecuaria (Corpoica). Colciencias. Fondo Nacional del Ganado.

Sánchez, L.; Amado, G.M.; Criollo, P.J.; Carvajal, T.; Triana, J.; Cuesta, A.; Conde, A.; Umaña, A.; Bernal, L.M.; Barreto, L. (2009). El aliso (Alnus acuminata H.B.K.) como alternativa silvopastoril en el manejo sostenible de praderas en el trópico alto colombiano. Corporación Colombiana de Investigación Agropecuaria (Corpoica). Bogotá, Colombia: Ed. Produmedios. 56p.

Santana, A.; Gómez, M.A.; Gutiérrez, J.I.; Cubillos, 0.J. (2013). Costos modales en ganadería de leche, trópico alto de Colombia: ventaja a la competitividad ganadera. Bogotá, Colombia: Federación Colombiana de Ganaderos (FEDEGAN). 102p.

Silva, A., Gómez, A., Landazury, B.; Preciado, B. (2013). Evaluación de gases de efecto invernadero (GEI) en sistemas ganaderos asociados con pasto Kikuyo (Pennisetum clandestinum Hoechst Ex Chiov). Revista Colombiana de Ciencia Animal. 6(1): 36-43.

Van Soest, P.J.; Robertson, J.B.; Lewis, B.A. (1991). Methods for dietary fiber, neutral fiber and no starch polysaccharides in relation to nutrition. J. Dairy Sci. 74: 3583-3597. doi: https://doi.org/10.3168/jds. S0022-0302(91)78551-2

Vargas, J.; Sierra, A.; Benavidez, J.; Avellaneda, Y.; Mayorga, 0.; Ariza, C. (2018). Establecimiento y producción de raigrás y trébol en dos regiones del trópico alto colombiano. Agron. Mesoam. 29(1): 177-191. doi:10.15517/ma.v29i1.28077

Vásquez, D.R.; Abadía, B.; Arreaza, L.C. (2004). Aplicación de la espectroscopia de reflectancia en el infrarrojo cercano (NIRS) para la caracterización nutricional del pasto guinea y del grano de maíz. Corpoica Cienc. Tecnol. Agropecuaria. 5(1): 49-55. doi: https://doi.org/10.21930/rcta.vol5_num1_art:24 